\title{
Mental Impediments to Desirable Social Transformation in Contemporary Africa
}

\author{
Reginald M.J. Oduor \\ Department of Philosophy and Religious Studies \\ University of Nairobi \\ rmjoduor@uonbi.ac.ke \\ Thought and Practice: A Journal of the Philosophical Association of Kenya (PAK) \\ Premier Issue, New Series, Vol.1 No.1, June 2009, pp.1-29 \\ thoughtandpractice@uonbi.ac.ke OR thoughtandpractice@gmail.com
}

\begin{abstract}
A bstract
Africa's current socio-economic predicament is often solely attributed to political and economic mismanagement. However, such an analysis is far from comprehensive, as it fails to account for the historical, sociological and psychological causes of the current unsatisfactory social conditions in the continent. Consequently, using the critical and prescriptive techniques of philosophic reflection, this paper examines four apparent mental impediments to desirable social transformation in contemporary Africa, namely, conservatism, feeble social consciousness, blind acceptance of the white-black dichotomy, and a fixation with foreign paradigms of managing public affairs. The paper calls for an interdisciplinary approach to the verifying, mitigating and/or eliminating of these impediments.
\end{abstract}

\section{Introduction}

Almost half a century since most African countries attained political independence, Kwame Nkrumah's prophecy that political independence would certainly be followed by all-round prosperity has not been fulfilled. Instead, Africa is now plagued by the HIV-Aids pandemic, an increasing number of failed states, violent inter-state and intra-state conflicts, still-born pluralistic governance systems, rapidly deteriorating social services, all of which have culminated in spiraling poverty. Thus the majority 
of the population of the continent which supplies the bulk of the world's highly sought after minerals and agricultural produce now wallows in abject poverty. Yet the plight of contemporary Africa goes deeper than the state of her economy. Through the process of Westernisation lately referred to as "globalization", the continent has lost the bulk of its traditional communalistic values. Thus Africa now stands at the crossroads of history: how does she ensure she is a formidable player in the global scene, without her culture being swamped by foreign worldviews that often encourage ravaging individualism in the place of constructive communalism?

The present paper explores four modes of thought that seem to hinder desirable social transformation in contemporary Africa. It is premised on Kwasi Wiredu's assertion that the task of philosophy is to examine the intellectual foundations of human life using the best available modes of knowledge and reflection for human well being (Wiredu 1980, 62). More specifically, in its quest for insight into apparent modes of thought that hinder desirable social transformation in contemporary Africa, this paper employs the critical and prescriptive techniques of philosophic reflection.

The critical technique of philosophic reflection is characterized by the questioning of beliefs whose truth is normally taken for granted. It lays great emphasis on independent and original thinking, which includes but transcends empirical investigation (Maritain 1979, 88-89). On its part, the prescriptive technique involves making reasoned recommendations on the course of action to be pursued in a given situation. It is mainly used in axiology, that is, the philosophical reflection on values. This kind of inquiry becomes necessary when people are no longer certain about what is worthwhile or valuable for their lives (Njoroge and Bennaars 1986, 17). Such uncertainty is usually caused by rapid social changes such as the ones Africa has experienced over the past two centuries. Thus what Wiredu observed almost thirty years ago is still true today, that "we are not only seeking modes of political and social organization best suited to the requirements of rapid development but also engaged in reappraising, changing and adapting our traditional culture under the pressure of modern conditions, under the pressure, more specifically, of a foreign influence that came to us first in the form of colonialism" (Wiredu 1980, 52). 
It is important to bear in mind that this paper does not seek to make the kind of generalizations associated with the so-called African mentality - the idea that Africans have a distinctively collective way of thinking. Thus the paper does not make claims such as that of Tempels (1959) that for the Bantu being is force, or that of Mbiti (1969) that Africans are notoriously religious. As Hountondji $(1983,62)$ aptly points out, such assertions are themselves subjective and therefore outside the ambit of rational debate. In contrast to such an approach, the present paper begins from the assumption that individual Africans are individual thinkers, but that as with human beings elsewhere, social realities do have an impact on the way they view themselves and the world around them, and that their consequent outlook has a bearing on how they act in that world (Brislin 1999).

The paper sets out by reflecting on the crucial place of thought as a distinctive feature of truly human action. It then examines the concept of desirable social transformation. This is followed by a discussion of the need for a social ideal - a "vision" - to give direction to the struggle for desirable social transformation in contemporary Africa. Thereafter, the paper reflects on four apparent mental impediments to Africa's social transformation, namely, conservatism, feeble social consciousness, blind acceptance of the white-black dichotomy, and a fixation with foreign paradigms of managing public affairs. The paper calls for an interdisciplinary approach to the verifying, mitigating and/or eliminating of these impediments. In view of the dearth of literature on the mental causes of Africa's current social crisis, this paper is written in the hope that it will encourage interdisciplinary research and debate on this vital issue.

\section{The Nature of M ental I mpediments}

Many students of the philosophy of man would agree with Kant (1785) that what distinguishes us human beings from other beings in the world is our ability to reason (Kelly and Tallon 1967). However, some psychologists insist that human action must be motivated, and motivation is centred on feelings rather than rationality (Maslow 1943; Daniels 2001; Nohria, et al. 2001). Nevertheless, it is difficult to gainsay the pragmatist contention that reason is crucial for an adequate account of the nature of 
human action. This is due to the fact that if we reason correctly, our emotions are likely to line up with our conclusions, resulting in the formation of convictions which are both justifiable and practicable. Indeed, the adage that "We are what we think" is apt, because human action is distinguished from brute action by the fact that the former issues from deliberation while the latter is a result of instinct. Even if we reason incorrectly, our emotions are likely to line up with our conclusions, but the actions resulting from that combination are likely to be inadequate responses to environmental stimuli, resulting in ill-adapted lives.

It is evident that our actions are the result of our thoughts. Thus the architect must first conceptualise a building before he/she can even sketch it out; the mason must then understand the design before he/she can lay down its foundation and construct its walls. It follows that a poorly conceived edifice will result in a poorly constructed building. Many philosophers have acknowledged the close connection between thought and action. In the Apology, Plato's Socrates pinpointed this connection when he declared that an unexamined life is not worth living (Woodhead 1953); Plato acknowledged it when in the Republic he stated that to know the good is to do the good (Plato 2009); Karl Marx affirmed it when he emphasized the crucial place of the awakened consciousness of the proletariat for an adequate response to the challenge of capitalism (McLellan 2000); Jeremy Bentham hoped that his utilitarian ideas would serve as catalysts for social and legal reforms (Bentham 1996); the pragmatist John Dewey was acutely aware of the connection between thought and action when he declared that the value of thought had to be judged in terms of how effectively it served as a tool with which the individual manipulated his/her environment to his/her advantage (Hickman and Alexander 1999).

Furthermore, the critical thinking movement is based on the appreciation of the fact that effective human action must proceed from adequate thought. As the Foundation for Critical Thinking puts it, "the quality of our life and that of what we produce, make, or build depends precisely on the quality of our thought. Shoddy thinking is costly, both in money and in quality of life. Excellence in thought, however, must be systematically cultivated" (Foundation 2008). For the critical thinking movement, the ideal society is one that is "continually improving. Its mostdistinguishing characteristic is its emphasis on thinking as the key to the emancipation of the mind, 
to the creation of just practices" (Elder and Cosgrove 2008). Highlighting the close connection between thought and action, William Graham Sumner, one of the $20^{\text {th }}$ century champions of critical thinking, wrote:

The critical habit of thought, if usual in society, will pervade all its mores, because it is a way of taking up the problems of life. Men educated in it cannot be stampeded by stump orators ... They are slow to believe. They can hold things as possible or probable in all degrees, without certainty and without pain. They can wait for evidence and weigh evidence, uninfluenced by the emphasis or confidence with which assertions are made on one side or the other. They can resist appeals to their dearest prejudices and all kinds of cajolery. Education in the critical faculty is the only education of which it can be truly said that it makes good citizens (cited in Elder and Cosgrove 2008).

Consequently, what we refer to as mental impediments are thought patterns that inhibit adherence to universal intellectual values such as clarity, accuracy, precision, consistency, relevance, sound evidence, depth, breadth, and fairness (Scriven and Paul 1987).

The manner in which members of a community respond to a single event can indicate the kind of unsatisfactory modes of thought that plague them. For example, the many near and actual disasters at scenes in which tankers carrying highly inflammable petroleum products have overturned on Kenyan roads reveals a most disturbing set of mental impediments. This year alone, the country has witnessed several such accidents. In each case, villagers have rushed to the scene, containers in hand, to "harvest" the oil products, totally oblivious of the danger to which they expose themselves. Consequently, scores of people have died so far from infernos that have broken out at such scenes. In rushing to acquire the oil products without seeking to find out about the well-being of the crue involved in the accident, the crowds manifest a saddening lack of human sympathy; in looting the products, they reveal a worrying deficit in their respect for other people's property; in exposing themselves to the real danger posed by such explosive products despite hearing of earlier disasters under similar circumstances, they exhibit shocking recklessness. Such behaviour is evidently not only due to material poverty, but also a function of mental impoverishment. 


\section{DesirableSocial T ransformation}

The term "social transformation" is often understood as the change in culture in response to such factors as economic growth, war, or political upheavals (Castles 2001, 15). Nevertheless, such a conceptualization unjustifiably limits this phenomenon to only that change which happens to society, ignoring that which is initiated by members of society. Yet scientific discoveries have triggered many social transformations throughout history, as have religious and royal edicts. Some countries have achieved almost entirely intentional social transformation, as did South Africa in 1994 when it ended apartheid. Thus Garonna and Triacca $(1999,49)$ have correctly underscored the need to understand social transformation as coming about through both voluntary and involuntary causes. The kind of social transformation which comes about through both natural causes and the deliberate actions of the members of a human group, and which contributes positively to the quality of human existence in the said group, is what we refer to here as desirable social transformation.

Nevertheless, we must not confuse desirable social transformation with social action a strategy by social workers to effect limited social change at the intermediate or macro levels of society (Khinduka and Coughlin 1975, 1). In view of the fact that a human person is rational by nature, any effort to effect social change through manipulation is morally unacceptable. As such, what this paper focuses on is the need for a sizeable proportion of members of society to become agents of positive change rather than pawns in a change chess game.

This paper focuses on desirable social transformation rather than social development, because the term "development" is associated with the coming to birth of the type of economy and society to be found in the "highly-developed" western countries (Castles 2001, 15). Focus on technological advancement fails to recognize the fact that mankind yearns not only for more efficient transportation, medical care or state-ofthe-art telecommunications, but also for the upholding of human values such as satisfactory interpersonal relationships and the freedom to think critically and creatively. Thus what we ought to aspire for in Africa today is a society in which 
individuals can actualize their potentialities for their own good and that of their fellow human beings. This will obviously include economic growth, but must also encompass aspects of human life such as art, history and philosophy, which do not have a direct impact on economic indicators such as gross national product and gross domestic product, but which nonetheless enrich human existence.

In the light of the foregoing observations, this paper views desirable social transformation as the process through which a human group experiences a beneficial recasting of various aspects of its material and conceptual culture through both voluntary and involuntary means. The voluntary input into this process presupposes that the human agents involved have examined various possible social arrangements, and identified the one which they deem to be most suitable for them. This brings us to the question of a social vision.

\section{The Need for an A frican Social Vision}

For an action to be truly human, it must be based on systematic thought that culminates in the identifying of specific objectives to be achieved by the said action (Wiredu 1980, 51). In the area of collective action, society relies for direction on its opinion leaders. With regard to the kind of socio-political order to be aspired for (a social vision), the contribution of political philosophers is crucial (Wiredu 1980, 5253). The essential nature of the task of political philosophers is to take what is known about human societies and the ways in which they are governed, and then to ask what the best form of government would be, in the light of aims and values that they believe their audience will share (Miller 2003, 14-15). Sadly, in Africa, many of those who have offered their social visions have been political ideologues, keen to give direction without an adequate conceptual framework and methodological finesse that would facilitate rigorous philosophic reflection. The African political philosopher must therefore serve as a sieve for such proposals (Wiredu 1980, 52-55).

Among the most prominent social visions presented by African politicians are Julius Nyerere's Ujamaa (Nyerere n.d., 1974, 1979) and Kwame Nkrumah's Consciencism (Nkrumah 1970), both of which were heavily socialistic. One of the more recent 
visions for a new Africa is former South African President Thabo Mbeki's African Renaissance (Mbeki 1998). The idea of an African Renaissance was foretold by one of the founders of the African National Congress, Pixley ka Izaka Seme, when he spoke thus at New York's Columbia University in 1906:

The African people ... possess a common fundamental sentiment which is everywhere manifest, crystallizing itself into one common controlling idea ... The regeneration of Africa means that a new and unique civilization is soon to be added to the world (cited in Lotter 2007).

Furthermore, twenty-two years before Mbeki's memorable speech on this subject, Kihumbu Thairu had stated:

Like all civilizations, ours in Africa collapsed under various vandals who destroyed what they could not recreate. Most of Africa was in a long "medieval" period, till the sound of European guns woke it up again .... We are, believe it or not, experiencing our renaissance and we shall soon catch up with the rest of the world and then surpass them (Thairu 1975, 150).

According to Mbeki, the African Renaissance is a vision of continental renewal/reconstruction and reawakening, based on the following five elements:

- Economic recovery of the African continent as a whole.

- Ability to establish political democracy throughout the continent.

- Demolition of neo-colonial relations between Africa and the world economic powers.

- Mobilization of Africans to reclaim as well as direct the continent's destiny.

- Acceleration of people-centered or people driven economic growth and development.

Mbeki goes on to identify the undesirable conditions, which the renaissance will dispel, as poverty, hunger, backwardness and marginalization (Mbeki 1998).

Examining Mbeki's vision, one notices a salient shortcoming which it shares with many other previous social visions, that is, it gives the misleading impression that if only Africa could have a robust economy facilitated by a Western type liberal democracy, her reality would have met her dream. While a comprehensive African social vision is well beyond the scope of this paper, it is noteworthy in passing that the Africa we must aspire for is one which is truly humane, catering for the individual's material, psychological, social and spiritual well being. For such an Africa to emerge, we must take action on several political fronts, including the international arena, regional and local politics. Equally crucial is the need to re- 
examine our own modes of thought, with a view to determining whether or not they facilitate the pursuit of our true interests.

\section{Four A pparent M ental I mpediments to Desirable Social Transformation in C ontemporary A frica}

What is it that motivates African political elites to make decisions out of short term personal expedience, instead of taking into account the long-term good of their countries? What encourages the African masses to behave in a manner suggesting that were they to get the opportunity, they would commit the same atrocities now being committed by the political leaders who currently impoverish them? It seems probable that the answers to these questions are partly related to modes of thought that guide the actions of African masses and leaders. In other words, there seems to be a causal connection between certain modes of thought on the one hand, and the political and economic mismanagement in contemporary Africa on the other. Consequently, in this section, we examine four apparent mental impediments to Africa's desirable social transformation, with a view to encouraging further research on them.

\section{Conservatism}

By conservatism, I refer to the inclination to maintain a traditional order. Africa has experienced astronomical changes - modes of governance, transport, communication, trade and inter-ethnic relations are all significantly different from the way they were two centuries ago. All these changes were thrust upon communities, each of which had a rich heritage that had enabled it to be productive and fulfilled in its environment. Despite Mbiti's contention that preoccupation with the past is a distinctively African outlook (Mbiti 1969, 16-17), it is actually typical of pretechnologised, pre-urbanized traditional societies all over the world to be retrospective. Yet in the fast-changing world in which we live, a preoccupation with the past is a great impediment to innovation, since solutions to new problems cannot be found in the past where they had not been encountered. The Igbo saying concerning Eneke the bird, who learned to fly without perching because men had learned to shoot without missing, is apt in this regard. In the succeeding paragraphs of 
this section, I examine a number of manifestations of conservatism which hinder desirable social transformation in Africa today, namely, adherence to antiquated customs, uncritical veneration of African cultures, communal authoritarianism, imprecise handling of modern technology, poor management of time, and belief in fatalism.

\section{Adherence to Antiquated Customs}

With the advent of the industrial revolution coupled with massive urbanization, European masses were forced to cast off their preoccupation with the past, and to adjust to the future-oriented society in which they found themselves. However, despite having experienced considerable industrialization and urbanization, African masses seem to be locked in the backward-looking worldview of their forefathers. How else can we explain the veneration of past cultural artifacts, even when their usefulness has been evidently superseded by new innovations? Is there any other explanation for the fact that our politicians easily win the hearts of the masses by adorning indigenous African regalia during political rallies, only to abandon them for Western suits in the corridors of legislative and executive power?

There are many customs which were of great utility in the pre-colonial African past, but which currently serve to diminish the quality of human life. For example, among the Luo of Kenya, it is a taboo for a parent to spend a night under the same roof with his/her married son or daughter. Sadly, this custom persists despite drastically changed conditions. In the contemporary urban setting, young Luo couples often have to travel considerable distances to take their parents to a different house to lodge for the night, even when they have spacious guest wings. If only the members of this community would ask themselves why the taboo was there in the first place, they would probably come to the understanding that it was instituted in the context of the single-roomed huts in which families lodged in the past, and that in the contemporary urban setting with spacious guest wings and difficulty of intra-city travel, such a custom is enslaving and retrogressive.

Similar instances of anachronistic customs can be cited from many other Kenyan communities: the Kikuyu insistence that the bride sets out from her mother's house even if it means traveling vast distances on the wedding day, the Bukusu insistence on 
sharing the traditional circumciser's knife despite the glaring danger of HIV-Aids infections, the intransigent perpetuation of female circumcision among the Maasai, and the insistence in many communities that only sons inherit their fathers' estates are all cases in point.

\section{Uncritical Veneration of African Cultures}

Following the thoughts of their opinion leaders such as G.F.W. Hegel and Diedrich Westermann, European colonialists systematically and consistently disparaged African cultures (Ochieng'- Odhiambo 1997, 1-18). They conditioned Africans to be subservient to European domination through missionary work, violence, and the school system, with the most effective element of this tripartite de-culturation being the school system (Thairu 1975, 1-15). Thus due to the colonial education system, many Africans came to share the colonialists' view that Africans had no culture and therefore no history. Indeed, even today, many Kenyans use the Kiswahili word kienyeji ("traditional") to refer to any improvisation considered to be crude and inefficient. Consequently, the inclusion of indigenous African songs in national music festivals, the incorporation of African motifs in urban architecture, the production of literary works in African languages, and the inclusion of African cuisine in restaurants, all help to affirm to the African that he/she has a rich heritage, contrary to the colonialists' assertions. Indeed, movements such as Négritude and the African Personality have offered intellectual rationales for the assertion of the dignity of African culture.

However, just as the African's repudiation of his/her own culture is a function of colonialism, so is his/her uncritical veneration of it; for when the African responds to foreign cultural assaults by declaring that his/her culture is perfect, he/she thereby over-reacts to the challenge, thus still responding to the colonial assault rather than thinking independently and in a self-assured manner. Furthermore, an uncritical veneration of one's culture means that one is avoiding the responsibility of undertaking a thoroughgoing evaluation of its worth. This being so, those aspects of the culture that are truly contrary to human welfare are perpetuated instead of being abandoned. Africans need therefore to be secure enough to concede that although there is much that is of great value in their cultures, there is also a lot in them which is not worth being proud about - the killing of twins among the Igbo of Nigeria, cattle 
raids among pastoralist communities of East Africa, female circumcision, the subjugation and exploitation of women, and a heavy-handed approach to child-raising which discourages curiosity and critical thinking, among others.

At the intellectual level, the uncritical veneration of African cultures has led some scholars to urge that African philosophy is distinct from Western philosophy, and therefore beyond any scrutiny that relies on standards by which Western philosophy is judged. In this regard, Wiredu's caution ought to be heeded:

To present African philosophy as an untouchable possession of Africans is to invite a touristic approach from its foreign audiences. If the philosophies may not be evaluated as false, they may not be evaluated as true either. In that case they might merely be noticed as cultural curiosities (Wiredu n.d.).

Africans must therefore be proud of their cultures, but also be committed to subjecting them to scrutiny. In this way, they shall be able to utilize all truly human aspects of their cultures, while abandoning all of their elements that inhibit desirable social transformation.

\section{Communal Authoritarianism}

The Kiswahili proverb, “Asiesikia la mkuu huvunjika guu (He who does not heed the word of a superior breaks his own leg)" is typical of the African reverence for the elderly. It could be argued that this reverence points to the Africans' high regard for experience, and ultimately for knowledge. In the pre-colonial African communities, the elderly served as points of reference for diverse kinds of knowledge. However, one negative effect of this outlook was the growth of authoritarianism - an emphasis on absolute obedience to superiors, rather than the cultivation of individual freedom and the attendant independent thinking. Wiredu (1980) aptly noted the highly authoritarian character of pre-colonial African communities:

Our social arrangements were shot through with the principle of unquestioning obedience to superiors, which often meant elders. Hardly any premium was placed on curiosity of those of tender age, or independence of thought in those of more considerable years. Our traditional culture is famous for an abundance of proverbs .... But it is rare to come across any which extol the virtues of originality and independence of thought (Wiredu 1980, 4). 
Along similar lines, Nyasani $(1997,129)$ identifies the traditional African family as a setting wherein the vertical power structure of the society is introduced and sustained as predominant over the freedom of individuals. He also argues that the African communal authoritarianism was conducive to the colonial subjugation of the continent (Nyasani 1997, 113-114).

Even in the post-colonial era, authoritarianism continues to be one of the key impediments to desirable social transformation. While it is true that with increased modernization and urbanization the youth enjoy unprecedented personal freedom, it seems that a sizeable proportion of many African populations still defer to elders in matters such as rites of passage and indigenous medicine. Authoritarianism also seems to partly account for the amazing docility with which Africans have endured decades of one-party one-man dictatorships. In Kenya for example, both Presidents Jomo Kenyatta and Daniel arap Moi were frequently referred to as "father of the nation", and this family idiom reinforced the idea that they deserved unquestioning deference, contrary to democratic theory and practice. Even the military coups that frequently supplanted the one-party autocracies were often motivated by the raw desire for power rather than by a desire to replace the one-party dictatorships with more open societies (Johnson, et al. 1984; Kposowa and Jenkins 1993; McGowan 2003). This is not to say that Africans have endured dictatorships more than people in other parts of the world - such a verdict would require reliable comparative statistics. Furthermore, the struggle for the return of pluralism, which began in the 1970s but gained great momentum in the mid 1980s, is evidence that docility is not the only characteristic of African masses (Vanhanen 2004; Ambrose 1995; Ihonvbere 2000).

Nevertheless, it is noteworthy that even with the reinstatement of pluralist politics, elderly politicians frequently seek to intimidate their younger competitors by claiming that the younger politicians owe them the respect that sons owe to fathers! Similarly, In Kenya, politicians across the political divide often use the endorsement of so-called ethnic councils of elders to manipulate the masses in their favour. Thus in the run-up to the 2007 Kenyan general elections, one Kenyan newspaper reported: 
President Kibaki is set to meet Kaya elders from the nine Mijikenda communities.

.... The President's move has been seen as part of his strategy to win Coast Province's support in this year's General Election.

.... Several opposition leaders have been spotted with Kaya elders in ceremonies that include seeking blessings and prayers.

.... According to the Mijikenda tradition, prayers, blessings or curses from a Kaya elder are 100 per cent effective (The Standard, January 2, 2007).

The authoritarian outlook worked well in pre-colonial times, when both social and technological changes were slow, and the survival of the group was largely dependent on mastering the accumulated tested and tried ways of doing things. However, in the information age in which we live, authoritarianism is a recipe for retrogression, because the younger members of society tend to embrace new innovations faster than the older ones. As such, the advice of the old is likely to fail to take into account the revolutionary socio-economic changes that the continent must adapt to if it is to compete in the global village of which it is now a part. Thus in place of traditional authoritarianism, Africa needs an open society, in which the experience of the old and the innovativeness of the young can be effectively utilized in the quest for desirable social transformation.

\section{Imprecise Handling of Modern Technology}

By technology, we refer to the application of scientific knowledge to the meeting of specific human needs. For instance, the body of knowledge subsumed under biology is science, while the application of that knowledge to the alleviation of human suffering is technology. Contemporary Africa has access to vast technologyelectrical power, motorized transportation, equipment for the mass production of various goods, among others. One of the apparent differences between pre-colonial African technology and modern technology is that the latter requires a high degree of precision. Electronic telecommunications, for example, require much more intricate calculation during design as compared to the talking drums. Could this difference be having a negative impact on our technological progress? An exhaustive answer would require the input of social scientists, with their empirical and comparative methodology. 
Nevertheless, it seems evident that while a number of Africans have excelled in areas such as information technology, medicine and telecommunications, Africa is not drawing maximum benefit from modern technology because of an inadequate handling of it by a sizeable portion of her population. With regard to motorized transport, for example, one finds vehicles that are very poorly maintained, as is evident in unserviced wipers, extremely worn-out tyres, and vehicles that are overdue for routine service. It seems that the owners of these vehicles do not understand the law of nature that what is not maintained disintegrates. Wiredu $(1980,13)$ gave the now famous example of many an African mechanic's imprecise adjusting of the gap at the contact breaker point in the distributor of a car, resulting in many stalled vehicles. While the number of cars using contact breaker points is fast diminishing, Wiredu's example poignantly illustrates the crisis of Africa's technological revolution.

Furthermore, in our efforts to create jobs for our people, we have encouraged the development of the informal sector. However, the quality of the products of this sector often leaves much to be desired. For instance, often when one looks at furniture manufactured in this sector, the wood used is not properly dried, the furniture is vanished unevenly, and doors of cupboards or legs of tables leave a lot to be desired. When one questions, for example, the roadside carpenter as to why the workmanship is so lacking in precision, the carpenter will often retort, "There is nothing really wrong with the furniture!" While it could be argued that the imprecisely made furniture is commensurate to the money that a rural African carpenter's clientele is able to pay, the same kind of imprecision is often observed even in furniture sold in up- market shops in African cities.

The net loss of this African imprecision in the handling of modern technology is difficult to compute. What can be said with certainty is that it puts African countries at a disadvantage in their competition against economies such as those of the four Asian Tigers - Hong Kong, Singapore, South Korea and Taiwan - where meticulous skill is evident in the production of all sorts of wares, including electronic equipment. As Barro (1998) observed with regard to factors of economic growth, "The accumulation of huge amounts of capital and labor can work for a time, but ultimately must be backed by improvements in technology." We must therefore reform our 
education system to encourage precision in the handling of technology. The consuming public must also learn to demand products characterized by all-round finesse, rather than by basic functionality.

\section{Poor Management of Time}

Forty years ago, John S. Mbiti shocked many of his colleagues in the African academia, when he claimed that Africans do not have a substantive concept of the future, but rather that of a long past and a present (Mbiti 1969, 16-17). To buttress his position, Mbiti (1969, 17-19) reported that the three verb tenses in the Kikuyu and Kamba languages which refer to the future cover the period of about six months, and certainly no more than two years.

However, using the Luo language as a basis for his argument, Olela (1971) asserted that Africans do have a concept of the distant future. He also contended that "it is one thing to say that the Africans do not consider the future as important as the past and present, and completely another to deny the existence of the concept of future" (Olela 1971, 60). For Olela $(1971,61)$, the fact that Africans fear the possibility of evil befalling them as a consequence of displeasing the ancestors is yet another indicator of the Africans' apprehension of the future dimension of time.

Both Mbiti and Olela are guilty of hasty generalisation, since their inferences about the whole of sub-Saharan Africa are drawn from a study of the languages of one or two ethnic communities. Mbiti's position has the further weakness of assuming that if one cannot find a word for a concept in a particular language, then the owners of the language do not possess that concept. Indeed words are used to name what one already knows, so that it is quite conceivable for one to be aware of the existence of something, without having a name for it (Oduor 1990, 109).

Whether or not one agrees with Mbiti's account of the African conception of time, it is difficult to gainsay the fact that one of the challenges in contemporary Africa is the poor time management by its indigenous inhabitants. Meetings will often begin more than an hour after the scheduled time. This situation has even led to some people declaring false starting times for functions in an attempt to ensure that the accurate starting time is honoured. Furthermore, the meetings that begin well behind schedule 
are often characterized by long speeches, which suggest a total unawareness of the time lost.

In pre-colonial Africa, there was no need to view time as a scarce resource to be quantified as seconds, minutes and hours, because the pressures of modernity were unknown. However, in contemporary African societies aspiring to modernization, the meticulous management of time is of utmost importance, because the cost of time is inextricably bound up with the cost of labour, and this linkage is factored into the pricing of goods and services. As such, a society which treats time as an amorphous and non-binding entity cannot effectively compete with others that regard it as a prized resource. Thus if Africa is to experience desirable social transformation, her technocratic opinion leaders must re-double their efforts at helping their people understand that in the contemporary social milieu, time is a precious resource which they can ill afford to waste.

\section{Belief in Fatalism}

Fatalism is the doctrine that whatever happens has to happen regardless of what human agents do. This belief seems to involve a peculiar sense of necessity: it is neither logical nor causal necessity, and should not be confused with what is often called "determinism". Nor is fatalism theological necessity (as in "It's God's will"), for notions of fate thrive in many cultures that do not invoke the concept of God (Solomon 2003, 435). Fatalism is usually strongest in societies that have not experienced drastic scientific progress, with its great emphasis on material causes and effects. For example, the ancient Greek goddess, Themis, had three daughters called the Fates, who jointly determined the destiny of each individual (Lewis 2008). Similarly, fatalism seems to be rampant in many parts of sub-Saharan Africa. In Kenya, for example, many people see the course of their lives as bound to follow a pre-determined "graph". Thus quite frequently, a reckless Kenyan driver will declare that however he/she drives, he/she cannot die until his/her appointed day arrives. Dixey (1999) reports a similar outlook among the Yoruba of Nigeria.

Solomon $(2003,451)$ sees a distinction between belief in luck and belief in fatalism. For him, while the scientist and the fatalist seek for explanation, the believer in luck does not. Nevertheless, beliefs in fatalism and in luck seem to be very closely linked 
in many people's minds, as they see good luck as fate acting in their favour, and bad lack as fate acting against their interests. This fact is behind the saying that someone was born with a silver spoon in his/her mouth, meaning that fate/luck has marked $\mathrm{him} /$ her out for success. Indeed, one indicator of belief in fatalism is substantial talk about "luck". Thus very frequently, when an African lands a well-paying job, his/her relatives and friends will declare that he/she is "lucky".

An objector could point out that acquisition of jobs in Africa is very often dependent on family and ethnic networks rather than on personal merit. As such, the objection might run, it is understandable for Africans to adopt a fatalistic approach to the quest for jobs. However, accepting patronage as the order of the day and deferring to its oppressive modus operandi seems to the present author to be defeatist. Instead of yielding to patronage, Africans must work towards the growth of a social order governed by meritocracy and egalitarianism.

African intellectuals must therefore help their compatriots to understand that the logical implication of fatalism is utter inaction, because if fate determines the course of our lives, then we are helpless pawns in a mysterious destiny game. Those who believe in fatalism must therefore live inconsistently, because they make substantial effort to earn a living, take medicine to fight infections, lock their doors at night, among others, instead of leaving all these things to fate. Yet they are not likely to engage in maximal self-assertion in pursuit of self-improvement, believing that their endeavours amount to nothing in view of fate, thereby stunting desirable social transformation.

\section{Feeble Social Consciousness}

By social consciousness, I refer to awareness in individual members of society of their need for, and responsibility towards, other members of society. Thus a person with a feeble social consciousness is one who erroneously thinks that he/she is selfsufficient. Communalism in pre-colonial Africa is a well attested fact, encapsulated in a number of sayings. The Kiswahili proverb that mtu ni watu (literally "An individual is people"), and the Luo saying that ok inyal guonyo ng'eyi iwuon ("You cannot scratch your own back") are cases in point. However, due to the imposition of the 
individualistic Western model of political organisation, the indigenous ethnicallybased integrative socio-political formations have almost entirely disappeared. Nevertheless, while it is true that modernisation and its attendant urbanization result in societies with unsatisfactory human relationships, it does not necessarily follow that members of such societies fail to recognize their common interests. The solidarity of a substantial proportion of the US citizenry during the 2008 presidential elections illustrates this fact.

Yet in a number of African countries today, the populace has largely lost the sense of collective responsibility. This might largely explain the silence of the vast proportion of African populations as their dictatorial rulers exiled, tortured and murdered the few voices that challenged their hegemonies in the 1970s and 1980s. Even today, the apathy manifested in many general elections, the littering of our cities and towns, the diversion of public resources to personal use, all point to a feeble social consciousness - a failure to appreciate that if the social fabric were to collapse, all of us would be the worse for it, and desirable social transformation would remain a mirage.

\section{Blind Acceptance of the White-Black Dichotomy}

Scholars are generally in agreement that the concept of race is not an objective one. As Winant $(2000,172)$ has pointed out, "There is no biological basis for distinguishing human groups along the lines of race, and the socio-historical categories employed to differentiate among these groups reveal themselves, upon serious examination, to be imprecise if not completely arbitrary". Despite this fact, the idea of race is now so deeply engrained in society that anyone who challenges its use in the conception of social groupings runs against the real danger of being considered uninformed or destructive. That notwithstanding, philosophy must challenge this deep-seated notion, just as it confronts other false beliefs and ill-adapted practices.

It has become standard practice to speak of people of European origin as belonging to "the white race", and those of sub-Saharan African origin to "the black race". Yet these terms encourage subtle discrimination of sub-Saharan Africans on the basis of skin complexion. As Winant $(2000,171)$ notes, "the theme of race is situated where meaning meets social structure, where identity frames inequality". This unscientific 
use of "whiteness" and "blackness" continues to have a negative impact on the development of a healthy African identity.

By identity we refer to both a person's own and other people's understanding of the fundamental defining characteristics of the person as a human being. A crucial aspect of an individual's identity formation is the communication from other people about how they perceive him/her. Consequently, a person or group of people can suffer real damage if the people around them mirror back to them a demeaning picture of themselves, imprisoning them in a false, distorted, and reduced mode of being (Taylor 1994, 25). Persons with disabilities are well acquainted with this unsavoury experience, as many cultures refer to them in demeaning terms. For example, the Kiswahili word for a person with a visual disability is kipofu, and it falls in the same word-class as inanimate objects such as kijiko (spoon), kikombe (cup), or kikapu (basket). All these words are prefixed by the lettters " $k i$ ", denoting their impersonal nature. In contrast to this word-class, Kiswahili terms signifying living things are prefixed by the letter “m”, as mtu (person), mgeni (guest), mkulima (farmer), or even $m t i$ (tree)!

With the persistent denigration of Africans, some Africans have come to denigrate themselves as a matter of course. No wonder some African women bleach their skins in an attempt to appear like their European counterparts. Yet Africans have not always adored the skin complexion of people of European origin, but in fact initially found their appearance to be pitiable or amusing (Thairu 1975, 2). It is only through persistent multifaceted propaganda that some Africans eventually came to regard European skin as superior to their own.

An objector to the present point could assert that some non-African societies have progressed despite accepting the white-black dichotomy. Such an objector would probably be thinking of Western liberal democracies. Nevertheless, the objector's view of "progress" would have to be a purely material one, ignoring the glaring social inequalities so characteristic of such societies. Furthermore, while some might retort that "A rose will smell as sweet by any other name", that saying is itself controversial; for as Copi and Cohen $(2005,86-87)$ pointed out, "It is true that the actual fragrance of the rose would remain the same through any change of name we might assign it. 
But our attitude toward them would very likely change if we began to refer to roses as, say, "skunkweeds"”.

Between 1853 and 1855, Athur de Gobineau wrote four volumes entitled "Treatise on the Inequality of Human Races", in which he put the "white" race at the top of the racial hierarchy, and stressed the necessity of maintaining the purity of the "white" race. He further argued that the future of civilization naturally depended on the degree to which the "white" race could maintain its genetic purity, because only then could the supreme position of the "white" race in the world be secure, and only then could the "civilising influence" of the "white" race seep down to the inferior races such as Africans, Indians and Chinese (cited in Thairu 1975, 147). de Gobineau's racist views should encourage Africans to re-examine the reference to them as "black".

The experience of African Americans is very instructive in our quest for an understanding of the African predicament, because it affords us the opportunity for comparative analysis. African Americans have suffered racially based discrimination, first as slaves, then as dehumanized emancipated slaves, each of whom, under the socalled Jim Crow laws, was considered to be a fraction of a human being (Lyons 1998, 38; Morris 1999, 518). Due to their relentless struggle for equality, legislation was finally passed in the 1960s recognizing them as full citizens, but structures of discrimination continue to limit their opportunities in American society. As American ethnic and racial minorities have asserted their right to recognition, racism has adapted to this challenge. As Schiele $(2002,439)$ observes, the method through which European Americans maintain control over society's political, economic and cultural institutions has over the past few decades mutated away from domination by repression or terror to domination by seduction. Bonilla-Silva $(1997,476)$ had earlier noted that in contrast to race relations in the Jim Crow period, the practices that reproduce racial inequality in contemporary America (1) are increasingly covert, (2) are embedded in normal operations of institutions, (3) avoid direct racial terminology, and (4) are invisible to most Americans of European origin.

In the light of the foregoing observations, there is need to re-examine the significance of Barack Obama's 2008 US election victory. Obama's triumph stirred the hopes of socially disadvantaged people in many parts of the world, because they saw in him the 
possibility of moving from rags to riches through sheer determination. In Africa, the line has been that "one of our own" has ascended to the helm of the world's most powerful nation. We know his father was an indigenous Kenyan, while his mother a European American. Obama's kinsmen from Kogelo consider him to be wuod Kogelo ("son of Kogelo") from their patrimonial perspective. Though some Africans own Obama not necessarily because he is black, many own him because, purportedly, he is "black"; but is he? What is lost to most of those who own him because he is "black" is that even if Obama's mother was the one with African origins, he would still have been considered to be "black". Thus the only way to be "white" is to have parents both of whom have a European descent. The implication of this criterion of determining "whiteness" and "blackness" is that African blood, from whatever source, "pollutes" European blood!

Thus by claiming that Obama is "black", many Africans inadvertently assent to de Gobineau's prescription that any human being with the smallest amount of African blood is "black", so that the only way to be "white" is to have a total European parentage. In doing so, we thereby concede that our blood has a contaminating quality which stains anyone who has any amount of it flowing in his/her vains. Furthermore, notwithstanding the saying that "black is beautiful", "whiteness" is often associated with moral and rational purity and the attendant superiority, whereas "blackness" is associated with impurity and inferiority (Wolfenstein 1977, 163). Consequently, for Africans to accept that they are "black" and that Europeans are "white" is to assent to the purported superiority of Europeans.

It therefore seems urgent that indigenous Africans move decisively to reject any reference to them as "blacks" and to Europeans as "whites". Americans of African descent have long acknowledged this need, first rejecting the term "Negro", then "black Americans", and now prefer to be referred to as "African Americans". The use of demeaning terminology to refer to ourselves reinforces the poor self-concept that our erstwhile colonizers imposed on us, thereby reducing our confidence in our abilities, with the result that we remain less equipped to be agents of desirable social transformation. In the words of Brown (1993, 658), "efforts to resist domination can 
readily re-enforce it, if such resistance is cast in the code of the dominator. .... Thus, fuller emancipation would seem to require new forms of cultural, as well as political, representation".

\section{Fixation with Foreign Paradigms of Managing Public Affairs}

Around the time when African countries were gaining their political independence,

Frantz Fanon warned them against imitating their erstwhile colonizers:

If we want to turn Africa into a new Europe ..., then let us leave the destiny of our countries to Europeans. They will know how to do it better than the most gifted among us.

But if we want humanity to advance a step further, if we want to bring it up to a different level than that which Europe has shown it, then we must invent and we must make discoveries (Fanon 1963, 315).

Nevertheless, many post-colonial African political and academic leaders have assumed that the European-type nation-state is the only possible model for managing the nascent independent African societies. For them, pre-colonial African political thought had nothing to offer for the creation of post-colonial political systems. Concerning this Thairu (1975) observed:

The problem with modern Africans is their phenomenal ability of copying other nations. ... You will hear such people praise or decry communism, socialism, capitalism etc., etc. If you talk to them of an African system which may even antedate any of these imported "isms" they try hard to label it under one or other of the non-African isms. If they fail they dismiss the African system as lacking in "ideological content" (Thairu 1975, 200).

Quite often, when there have been debates about the need for fundamental constitutional reforms in African countries, the options widely discussed have their origins in the West. For example, Kenyans have long been made to believe that if they adopt a parliamentary system of governance, they must, at the very least, have both a president and a prime minister. Clearly the paradigm in view is the Westminster one, with a monarch as head of state and a prime minister as head of government. The possibility of adopting the South African model, where the president is both head of state and government, but is chosen by parliament, is rarely, if ever, considered. Yet the South African model has several evident advantages over the Westminster one: it gives parliament more power as the appointing authority of the president; it lowers the stakes in the struggle for the presidency, thereby promoting stability; it facilitates smooth transitions, as the speaker of parliament is the interim head of state in the 
absence of a president; it promotes inter-party co-operation in the effort to acquire parliamentary majority in quest for the presidency; it cuts down costs, as there is only one high office to finance (see Oduor 2008).

Furthermore, quite often, the idea of desirable social transformation evokes in many African minds images of a continent with subways, super-highways, villages lit up by electrical energy, among others. It is as though if only we could have all those common services in place in our continent, we would have very closely approximated utopia. I am not suggesting that we have nothing to learn from the West or East about good road, rail, water and air transportation, efficient air ticketing and check-in services, all augmented by an information super-highway. Nevertheless, a technologically sophisticated society without a humane soul is more dreadful than a purely robotic world. This is because the idea of society implies gratifying interaction among members of a human group. Yet in the highly technologised and individualistic Western societies, the individual is denied vital human contact. In the Daily Nation of Friday, January 1, 1999, there was an instructive article titled: "'Uncaring' Germans Fret over Deaths No One Notices". The article stated:

They found Wolfgang Dircks on his sofa in his small Hamburg apartment last month. He had died while watching television sometime before Christmas - five years ago.

.... A newspaper dated December 5, 1993 and an empty beer can were among the few clues police had about the time of his death.

... hardly a month passes in Germany without a similar report of an isolated soul having died weeks, months or even years before being discovered.

.... Exacerbating the problem is an efficient German banking system, where automatic monthly transfers for pensions, rents and other financial transactions make it possible for bank accounts to continue functioning for years after a person dies (Daily Nation, Friday, January 1, 1999, "Your Weekender Magazine", p.5).

On 30th December 2008 at about 9:30 a.m. Kenyan time, the British Broadcasting Corporation (BBC) carried an item about a Nigerian student in the UK, Akinyemi Akimpelu, who died in early May 2005, but whose decayed body was only accidentally discovered two months later when some children were retrieving their ball from a neighbour's garden. His family in Nigeria only got to learn about his death three years later. The programme further mentioned that about two hundred such cases are reported every month in the UK, and that the numbers were rising. 
It is therefore clear that a highly technologised human group with an individualistic outlook easily becomes a collectivity rather than a society. In sharp contrast to highly technologised Western societies, the so-called "backward" societies such as those in rural Africa seldom have such problems - the individuals in them need each other for basic survival, and so they interact closely and meaningfully, thereby developing healthy human feelings towards one another.

Yet African intelligentsia has not always emulated the West. In the 1960s to the 1980s, it was fashionable in African academia to be an avowed socialist after the manner of Eastern European regimes. Thus Frantz Fanon's prescriptions for young independent African nations (Fanon 1963), Walter Rodney's analysis of obstacles to African economic development (Rodney 1973), and the bulk of Ngugi wa Thiong'o's novels, plays and monographs, had fundamental Marxist assumptions. Nevertheless, despite the optimism of these scholars, capitalism vanquished socialism in the early 1990s.

It therefore seems urgent that African intellectuals engage in rigorous reflection in quest for the kind of social transformation that incorporates the benefits of modern technology, while retaining a truly human value system. We need to learn from our past failures, and to dare to improvise our own solutions to our unique problems. This need is made more manifest by the current crisis in the international capitalist system of which many African countries have endeavoured to be a part. Thus Thairu's exploration of insights which contemporary Africa could utilize from pre-colonial African economic arrangements (Thairu 1975, $200 \mathrm{ff}$.), no longer seems as pointless as it might have earlier seemed to African proponents of European capitalism and European socialism. 


\section{Conclusion}

This paper has identified four apparent mental impediments to desirable social transformation in contemporary Africa, namely, conservatism, feeble social consciousness, blind acceptance of the white-black dichotomy, and a fixation with foreign paradigms of managing public affairs. In view of the scanty literature on these four apparent mental impediments, their presentation here must be viewed as tentative, pending further research to verify or falsify them. In this regard, there is need for inter-disciplinary research. The humanities can shed light on the subjective significance of Africa's experience; the social sciences can provide the facts and figures needed for an accurate understanding of the continent's current realities; the natural sciences can continue to provide much needed insight into ways through which to confront the material challenges that diminish the quality of human life in the continent. In the conclusion to his seminal work, The African Civilization, Kihumbu Thairu stated:

We who write and have written for the African course are all colleagues fighting for the African, in the battle for mental liberation. Each of us contributing from the depths of his experience, intellect and feeling. I hope that more and more Africans will join in this battle and write freely and honestly till the cultural and technological revolution is completed (Thairu 1975, 217).

\section{References}

Ambrose, Brendalyn P. 1995. Democratization and the Protection of Human Rights in Africa: Problems and Prospects. Westport: Praeger Publishers.

Barro, Robert J. 1998. "The East Asian Tigers have Plenty to Roar About". BUSINESS WEEK, $\quad 27^{\text {th }} \quad$ April, 1998. www.economics.harvard.edu/faculty/barro/files/bw98_04_27.pdf

Bentham, Jeremy. 1996. An Introduction to the Principles of Morals and Legislation. Oxford: Clarendon Press.

Bonilla-Silva, Eduardo. 1997. "Rethinking Racism: Toward a Structural Interpretation". American Sociological Review, Vol.62 No.3, June 1997, pp.465-480. http://www.jstor.org/stable/2657316

Brislin, Richard. 1999. Understanding Culture's Influence on Behavior, 2nd Ed. Wadsworth Publishing. 
Brown, Richard Harvey. 1993. "Cultural Representation and Ideological Domination". Social Forces, Vol.71 No.3, March 1993, pp.657-676. http://www.jstor.org/stable/2579889

Castles, Stephen. 2001. "Studying Social Transformation". International Political Science Review, Vol.22, No.1, January 2001, pp.13-32. http://www.jstor.org/stable/1601283

Copi, I.M. and Carl Cohen. 2005. Introduction to Logic, $11^{\text {th }}$ edition. New Delhi: Prentice-Hall of India.

Daniels, M. 2001. Maslows's concept of selfactualization. http://www.mdani.demon.co.uk/archive/MDMaslow.htm

Dixey, R.A. 1999. "Fatalism', accident causation and prevention: Issues for Health Promotion from an Exploratory Study in a Yoruba town, Nigeria". Health Education Research, Vol.14 no.2, 1999, pp. 197-208.

Elder, Linda and Rush Cosgrove. 2008. "Critical Societies: Thoughts from the Past". www.criticalthinking.org

Fanon, Frantz. 1963. The Wretched of the Earth. Constance Farrington, trans. New York: Grove Weidenfeld.

--. 1968. Black Skin, White Masks.C.L. Markmann, Trans. New York: Grove Press.

Foundation for Critical Thinking. 2008. 'Defining Critical Thinking". www.Criticalthinking.org

Hegel, G.F.W. 1956. Philosophy of History. New York: Dover Publications.

Hickman, L. and T. Alexander, eds. 1999. The Essential Dewey. Bloomington: Indiana University Press.

Hountondji, Paulin J. 1983. African Philosophy: Myth and Reality. London: Hutchinson University Library for Africa.

Ihonvbere, Julius O. 2000. "Politics of Constitutional Reforms and Democratization in Africa". International Journal of Comparative Sociology, Vol.41 Issue 1.

Johnson, Thomas H., Robert O. Slater and Pat McGowan. 1984. "Explaining African Military Coups d'Etat, 1960-1982”. The American Political Science Review, Vol.78 No.3, September 1984, pp.622640. http://www.jstor.org/stable/1961833

Kant, Immanuel. 1785. Fundamental Principles of the Metaphysic of Morals. Thomas Kingsmill Abbott, Trans. http:// eserver.org/philosophy/kant/metaphys-ofmorals.txt

Kelly, William L., and Andrew Tallon. eds. 1967. Readings in the Philosophy of Man. New York: McGraw-Hill Book Co.

Khinduka, S.K. and Bernard J. Coughlin. 1975. "A Conceptualization of Social Action". The Social Service Review, Vol.49 No.1, March 1975, pp.1-14. http://www.jstor.org/stable/30015183

Kposowa, Augustine J. and J. Craig Jenkins. 1993. "The Structural Sources of Military Coups in Postcolonial Africa, 1957-1984". The American Journal of Sociology, Vol.99 No.1, July 1993, pp.126-163. http://www.jstor.org/stable/2781957

Lewis, Jone Johnson. 2008. "Themis: Goddess of Justice". http:// womenshistory.about.com/od/goddessgreece/p/themis.htm

Lotter, Karen. 2007. "African Renaissance: The Renewal and Rebirth of a Continent". http:// africanaffairs.suite101.com/article.cfm/african_renaissance

Lyons, David. 1998. "Moral Judgment, Historical Reality, and Civil Disobedience". Philosophy and Public Affairs, Vol. 27, No. 1, pp.31-49. 
Maritain, Jacques. 1979. An Introduction to Philosophy. London: Sheed and Ward.

Maslow, A. 1943. "A theory of human motivation". Psychological Review, 50, pp.370-396. http://psychclassics.yorku.ca/Maslow/motivation.htm

Mbeki, Thabo. 1998. "The African Renaissance, South Africa and the World”. Speech at the United Nations University, 9th April, 1998. www.unu.edu/unupress/mbeki.html

Mbiti, J.S. 1969. African Religions and philosophy. London: Heinemann Educational Books.

McGowan, Patrick J. 2003. “African Military coups d'état, 1956-2001: Frequency, Trends and Distribution". The Journal of Modern African Studies, Vol.41 No.3, September 2003, pp.339-370. http://www.jstor.org/stable/3876235

McLellan, David ed. 2000. Karl Marx: Selected Writings, 2nd edition. Oxford: Oxford University Press.

Miller, David. 2003. Political Philosophy: A Very Short Introduction. Oxford: Oxford University Press.

Morris, A. 1999. "A Retrospective on the Civil Rights Movement: Political and Intellectual Landmarks". Annual Review of Sociology, Vol.25, 1999, pp.517539.

Njoroge, R.J. and G.A. Bennaars. 1986. Philosophy and Education in Africa. Nairobi: Transafrica Press.

Nkrumah, Kwame. 1970. Consciencism: Philosophy and Ideology for De-colonization. Revised ed. New York: Monthly Review Press.

Nohria, N., P. Lawrence, and E. Wilson. 2001. Driven: How human nature shapes our choices. San Francisco: Jossey-Bass.

Nyerere, J.K. n.d. Ujamaa: Essay on African Socialism. London: Oxford University Press.

--. 1974. Man and Development. Dar-es-Salaam: Oxford University Press.

--. 1979. "Education for Self-Reliance". The Tanzanian Experience, Hinzen, H. and Hundsdorfer, V.H. (ed.s). London: Evans Brothers Ltd.

Ochieng'-Odhiambo, F. 1997. African Philosophy: An Introduction, Second Edition. Nairobi: Consolata Institute of Philosophy.

Oduor, Reginald M.J. 1990. "Social Education and Ethics Programme: Its Main Sources and their Justification in Post-Colonial Kenya". Unpublished M.A. Thesis, Kenyatta University.

--. 2008. "Adopt South African System of Government". The Standard, Friday 3rd October, 2008. www.eastandard.net

Olela, H. 1971. "The Rationale for an African Philosophy: a Critical Examination of the African Cosmological Views with Some Reference to the Luo Beliefs". Michigan: University Microfilms International, Ann Arbor. Ph. D thesis in the Florida State University.

Oruka, H. Odera. 1990. Trends in Contemporary African Philosophy. Nairobi: Shirikon Publishers.

Nyasani, J.M. 1997. The african psyche. Nairobi: University of Nairobi Press Ltd.

Passmore, John. 1968. A Hundred Years of Philosophy. Middlesex: Penguin Books Ltd.

Plato. 2009. The Republic. Benjamin Jowett, Trans. N.P.: The Internet Classics Archive. http://classics.mit.edu/Plato/republic.html

Schiele, Jerome H. 2002. "Mutations of Eurocentric Domination and Their Implications for African American Resistance". Journal of Black Studies, Vol.32 No.4, March 2002, pp.439-463. http://www.jstor.org/stable/3180885 
Scriven, Michael and Richard Paul. 1987. "A statement". Presented at the 8th Annual International Conference on Critical Thinking and Education Reform, Summer 1987. www.criticalthinking.org

Rodney, Walter. 1973. How Europe Underdeveloped Africa. Dar-Es-Salaam: Tanzanian Publishing House.

Taylor, Charles. 1994. "The Politics of Recognition”. In Taylor, Charles et. Al. 1994, pp.25-73.

Taylor, Charles, K. Anthony Appiah, JÜrgen Habermas, Steven C. Rockefeller, Michael Walzer and Susan Wolf. 1994. Multiculturalism: Examining the Politics of Recognition. Gutmann, Amy ed. Princeton, NJ: Princeton University Press.

Tempels, P. 1959. Bantu Philosophy. Paris: Presence Africaine.

Thairu, Kihumbu. 1975. The African Civilisation. Nairobi: Kenya Literature Bureau.

Vanhanen, Tatu. 2004. "Struggle for Democracy in Sub-Saharan Africa". Acta Politica, 2004, 39, pp.207-247. www.palgrave-journals.com/ap

Westermann, Diedrich. 1934. The African Today. London: Oxford University Press.

Winant, Howard. 2000. "Race and Race Theory". Annual Review of Sociology, Vol.26, 2000, pp.169-185. http://www.jstor.org/stable/223441

Wiredu, Kwasi ed. 2007. "Introduction: African Philosophy in Our Time". http://doi.wiley.com/10.1002/9780470997154.ch1

Wiredu, Kwasi. 1980. Philosophy and an African Culture. Cambridge: Cambridge University Press.

--. N.d. "Toward Decolonizing African Philosophy and Religion". African Studies Quarterly. http://web.africa.ufl.edu/asq/v1/4/3.htm

Wolfenstein, Eugene Victor. 1977. "Race, Racism and Racial Liberation". The Western Political Quarterly, Vol.30 No.2, June 1977, pp.163-182. http://www.jstor.org/stable/447404

Woodhead, W.D. ed. 1953. Plato: Socratic Dialogues. Edinburgh: Thomas Nelson and Sons Ltd. 